\title{
İki Ucu Keskin Bıçak: Kolistin Yüksek Doz C Vitamini ile Nefrotoksisite Önlenebilir mi?
}

\section{Double-edged Knife: Can Colistin Nephrotoxicity be Prevented with High Doses of Vitamin C?}

Hüseyin Aytaç ERDEM' (ID), Çig̃dem YILDIRIM'(ID), Pervin KORKMAZ EKREN²(ID), Deniz AKYOL'(IDD), Meltem IȘIKGÖZ TAȘBAKAN'(ID), Mehmet Sezai TAȘBAKAN²(iD), Hüsnü PULLUKÇU'(IiD), Feza BACAKOG̃LU²(IDD)

\footnotetext{
${ }^{1}$ Ege Üniversitesi Tıp Fakültesi, İnfeksiyon Hastalıkları ve Klinik Mikrobiyoloji Anabilim Dalı, İzmir, Türkiye

${ }^{2}$ Ege Üniversitesi Tıp Fakültesi, Göğüs Hastalıkları Anabilim Dalı, İzmir, Türkiye
}

Makale atıfi: Erdem HA, Yıldııım Ç, Korkmaz Ekren P, Akyol D, Işıkgöz Taşbakan M, Taşbakan MS ve ark. iki ucu keskin bıçak: kolistin yüksek doz C vitamini ile nefrotoksisite önlenebilir mi? FLORA 2021;26(2):303-10.

\section{ÖZ}

Giriş: Bu çalışmada sistemik kolistin sodyum tedavisi alan hastalarda akut böbrek hasarı (ABH) gelişimi için risk faktörlerinin ve askorbik asidin nefrotoksisite gelişimi üzerine olan etkisinin araştırılması amaçlanmıştır.

Materyal ve Metod: Hastanemizde 2014-2019 yılları arasında yatarak sistemik kolistin sodyum tedavisi alan ve tedavi başlangıcında böbrek fonksiyon testleri normal olan hastalar retrospektif olarak değerlendirilmiştir. Hastaların demografik bilgileri, sistemik kolistin endikasyonları, ek antibiyotikler ve nefrotoksik ilaçlar, vazopressör gerekliliği, günlük kreatinin değerleri, akut böbrek hasarı gelişimi, askorbik asit tedavisi alıp almadığı kaydedilmiştir. Akut böbrek hasarı Kidney Disease Improving Global Outcomes (KDIGO) 2017 rehberine göre değerlendirilmiştir.

Bulgular: Çalışmaya dahil edilen toplam 66 hastadan sistemik kolistin ile birlikte günde üç gram askorbik asit alan 33 hasta ile sadece sistemik kolistin tedavisi alan 33 hasta retrospektif olarak değerlendirilmiştir. Askorbik asit alan grupta olguların 12'sinde (\%36.4) akut böbrek hasarı gelişirken, almayanların 15'inde (\%45.5) gelişmiştir ( $p=0.617)$. Askorbik asit alan hastalarda akut böbrek hasarı 9.1 \pm 5.9 günde gelişirken, almayanlarda $7.1 \pm 4.4$ günde gelişmiştir $(p=0.314)$. Askorbik asit alan hastalarda septik şok gelişme oranı anlamlı olarak daha düşük bulunmuştur (\%30.3 vs \%57.6, $p=0.046)$. ileri yaş $(p=0.005)$, sepsis varlı̆ı $(p=0.046)$ ve kardiyak hastalık varlığı $(p=0.01)$ nefrotoksisite gelişimi açısından istatistiksel olarak anlamlı bulunmuştur.

Sonuç: Çalışmamızda askorbik asit kullanımının kolistin ile ilişkili nefrotoksisite gelişimi üzerine istatistiksel olarak anlamlı etkisi saptanamamış olsa da kullanılan grupta $A B H^{\prime \prime}$ n daha az görülmesi, ciddi yan etkisi olmaması ve septik şokun önlenmesinde olumlu etkisi açısından yüksek doz C vitamininin seçilmiş hasta gruplarında faydalı olabileceğini düşünmekteyiz. Ancak bu konuda daha fazla hasta sayısı ile yeni araştırmalara gereksinim olduğu açıktır.

Anahtar Kelimeler: Kolistin; Askorbik asit; Nefrotoksisite 


\title{
ABSTRACT \\ Double-edged Knife: Can Colistin Nephrotoxicity be Prevented with High Doses of Vitamin C?
}

\author{
Hüseyin Aytaç ERDEM', Çig̃dem YILDIRIM', Pervin KORKMAZ EKREN², Deniz AKYOL', \\ Meltem IȘIKGÖZ TAȘBAKAN', Mehmet Sezai TAȘBAKAN², Hüsnü PULLUKÇU', Feza BACAKOG̃LU²
}

\footnotetext{
${ }^{1}$ Department of Infectious Diseases and Clinical Microbiology, Ege University Faculty of Medicine, İzmir, Turkey

${ }^{2}$ Department of Chest Diseases, Ege University Faculty of Medicine, Izmir, Turkey
}

Introduction: In this study, it was aimed to determine the risk factors for developing acute kidney injury (AKI) and effects of ascorbic acid on the development of nephrotoxicity in patients receiving systemic colistin sodium therapy.

Materials and Methods: We retrospectively reviewed records of cases who were treated with systemic colistin sodium and did not have any known renal disease in our hospital between the years of 2014 and 2019. The demographic characteristics, indications for systemic colistin, other antibiotics applied and nephrotoxic drugs, vasopressor necessity, daily creatinine values, development of acute kidney injury, and ascorbic acid use were evaluated. Acute kidney injury was assessed according to KDIGO 2017.

Results: Sixty-six patients were included in the study. In addition to colistin therapy, 33 cases who received at least three grams of ascorbic acid per day and 33 cases who received only colistin therapy were evaluated retrospectively. Acute kidney injury developed in 12 (36.4\%) of those receiving ascorbic acid and $15(45.5 \%)$ in those not receiving ascorbic acid ( $p=0.617)$. Acute kidney injury developed in $9.1 \pm$ 5.9 days in ascorbic acid patients and $7.1 \pm 4.4$ days in non-ascorbic acid patients $(p=0.314)$. The rate of septic shock development was significantly lower in patients receiving ascorbic acid (30.3\% vs $57.6 \%, p=0.046)$. Advanced age $(p=0.005)$, sepsis $(p=0.046)$, and underlying cardiac disease $(p=0.01)$ were found to be statistically significant in terms of the development of nephrotoxicity.

Conclusion: Although no statistically significant effect of ascorbic acid using on the development of colistin-related nephrotoxicity was determined in our study, we think that high dose vitamin C may be beneficial in selected patient groups in terms of the fact that AKI is seen less in the group using ascorbic acid, does not have serious side effects and has a positive effect on preventing from septic shock. However further research is needed with more patients.

Key Words: Colistin; Ascorbic acid; Nephrotoxicity

\section{GíRiș}

Alexander Fleming'in 1928 yilında tesadüfen keșfettiği Penicillium notatum ile bașlayan antibiyotik çăgında birçok yeni antibiyotik geliștirilmeye ve o dönemde ölümcül olan çoğu hastalık bașarı ile tedavi edilmeye bașlanmıștır. Günümüzde "yine-yeni-yeniden" kullandığımız kolistin (polimiksin E), 1940'lı yılların sonlarında Paenibacillus polymyxa subsp. colistinus adlı bakteriden elde edilen katyonik polipeptid yapıda, bes farklı kimyasal bileșenden (polimiksin A, B, C, D, E) olușan polimiksin grubu antibiyotiklerin bir üyesidir. Bunlardan sadece polimiksin B ve polimiksin E gerek tarım uygulamaları gerekse lokal tıbbi tedavi olarak on yıllardır dünyada yaygın olarak kullanılmaktadır ${ }^{[1,2]}$.

Bununla birlikte polimiksinlerin parenteral kullanımı ciddi nefrotoksisite ve nörotoksisite gibi yan etkileri nedeniyle 1980 'li y1llarda terk edilmiş, yerine daha az yan etkisi olan yeni grup antibiyotikler tercih edilmeye bașlanmıstır. Ancak son yıllarda cok ilaca dirençli ve genișlemiș ilac direnci olan gram-negatif basillerle olușan infeksiyonlarn tedavisinde kolistin tekrar kullanilma girmistir. Coğu infeksiyonda kaçınılmaz olarak tedavide yer alması gereken kolistinin kullanımını kısıtlayıcı en önemli yan etkisi nefrotoksisitedir ${ }^{[3,4]}$.

"İlacı zehirden ayıran dozudur". Toksikoloji biliminin kurucularından kabul edilen ünlü İsviçreli hekim ve kimyager Theophratus Bombastus von Hohenheim, diğer ismi ile Paracelsus'un henüz 16. yüzyılda dikkat cektiği ilaçların akılcı kullanımı ve yan etki sorunu hala modern tıbbın cözmeye çalıștğ̆ bir konudur ${ }^{[5]}$. Kolistin iliskili nefrotoksisite prevalansı ile ilgili yapılan çalısmalar arasında kullanılan yöntemlere de bağlı olarak farklllıklar olmakla birlikte, nefrotoksisite oranı \%0-53.5 ara- 
sında değismektedir ${ }^{[6]}$. Özellikle akut böbrek hasarı $(\mathrm{ABH})$ siklıkla tedavinin 5-7. günlerinde siklikla hafif dereceli renal fonksiyon bozukluğu olarak gelismesine rağmen, nadiren de renal replasman tedavi ihtiyacı ve kalıcı hasar görülebilmektedir ${ }^{[7]}$. Kolistin yan etkilerini azaltmak için literatürde uzun süreli infüzyon, $\mathrm{N}$-asetil sistein (NAC) veya yüksek doz askorbik asit kullanımı gibi uygulamalar denenmis ve bu uygulamaların faydalı olduğu gösterilmistirir ${ }^{[7-9]}$. Özellikle askorbik asit kullanımının ciddi bir yan etkisinin olmaması ve sınırlı sayıda da olsa etkinliğini destekleyen yayınlar bulunması nedeniyle kolistine bağlı gelișen nefrotoksisitenin önlenmesi amacıyla kullanımı düșünülebilir ${ }^{[7]}$. Bu calıșmada kolistin ile es zamanl askorbik asit tedavisi alanlar ile sadece kolistin tedavisi alan hastaların nefrotoksisite gelissimi açısından retrospektif olarak değerlendirilmesi amaçlanmıștır.

\section{MATERYAL ve METOD}

Hastanemizde 2014-2019 yılları arasında Göğüs Hastalıkları ve İnfeksiyon Hastalıkları ve Klinik Mikrobiyoloji kliniklerinde yatarak sistemik kolistin sodyum tedavisiyle birlikte $3 \mathrm{gram} /$ gün askorbik asit tedavisi alan hastalar ile sadece kolistin sodyum tedavisi alan olguların kayitları hastane elektronik bilgi sistemi kullanılarak retrospektif olarak değerlendirilmiștir. Calıșmaya kolistin tedavisi 5 $\mathrm{mg} / \mathrm{kg}$ (ideal vücut ağırlığına göre) yükleme dozu ardından; $5 \mathrm{mg} / \mathrm{kg}$ (ideal vücut ağırlığına göre)/ gün, 2 eșit dozda damar içi yolla uygulanmıs olan olgular dahil edilmiștir. Yetmiş iki saatten kısa süre kolistin alan hastalar, ikinci kez kolistin tedavisi alanlar, kolistine bașlandıktan sonra 48 saat içinde akut böbrek hasarı gelisenler, renal replasman tedavisi (hemodiyaliz veya periton diyalizi) alan hastalar, renal replasman tedavisi gerekmeksizin kronik böbrek yetmezliği tanısı ile takip edilen hastalar calıșma dıșı bırakılmıștır.

Takipte akut böbrek hasarı "Kidney Disease Improving Global Outcomes" (KDIGO) rehberine göre belirlenmiștir ${ }^{[10]}$. Septik sok tanımlaması sepsis sağkalım kampanyası 2016 rehberine göre yapılmıstır ${ }^{[11]}$. Hastaların demografik bilgileri, kolistin endikasyonları, kullandığı diğer antibiyotikler, inhaler kolistin kullanımı, kontrast madde ve nefrotoksik diğer ilaçların kullanımı, inotrop ya da vazopressör tedavisi, septik sok varlığı, günlük kreatinin değerleri, tedavi sırasında $\mathrm{ABH}$ gelișimi,
$\mathrm{ABH}$ geliști ise kaçıncı günde geliștiği, yan etkileri azaltmak için uygulanan ilaç ve yöntemler hasta gözlem formlarına kaydedilmiștir. Bu calıșma için Ege Üniversitesi Tip Fakültesi Tıbbi Araștırmalar Etik Kurulundan (29/05/2020-20-5.IT/51) onay alınmıstır.

Veriler standart olgu rapor formuna kaydedildikten sonra "Data Statistical Package for the Social Sciences software version 22 (SPSS Inc., Chicago, IL, USA)" programı kullanılarak analiz edilmiștir. İstatistik analiz sırasında Student's t-test, Mann-Whitney U ve ki-kare testleri kullanılarak $\mathrm{p}<$ 0.05 istatistiksel olarak anlamlı kabul edilmiștir.

\section{BULGULAR}

Hastanemiz Göğüs Hastallkları ve İnfeksiyon Hastalıkları ve Klinik Mikrobiyoloji kliniklerinde; 2014-2019 yılları arasında sistemik kolistin tedavisi ile birlikte askorbik asit tedavisi alan 58 hasta olduğu saptanmıștır. Olguların 33'sine 3 gram/gün dozunda askorbik asit verildiği, kalan 25 hastaya farklı dozlarda askorbik asit ve/veya kolistin uygulandığı görülmüs ve bu hastalar calıșma dıșında bırakılmıștır. Bu dönemde içinde sadece sistemik kolistin uygulanmıs 33 hasta çalıșmaya dahil edilerek diğer retrospektif kohort grubu olușturulmustur.

Calıșmaya dahil edilen 66 hastanın, 44'ü erkek ve yas ortalaması $65.2 \pm 19.5$ (22-97) idi. Kolistin en cok hastane kaynakl pnömoni, ventilatör ilișkili pnömoni ve üriner sistem infeksiyonu nedeniyle kullanılmıstır. Olgular askorbik asit kullanım durumuna göre karșılaștırıldığında ek hastalıklardan malignite varlığı dıșında gruplar arasında fark yoktur (Tablo 1). Hastaların sekizine ampirik olarak kolistin bașlanırken 58'sine etkene yönelik tedavi bașlanmıștır. En sik saptanan etkenler ise sırasıyla Acinetobacter baumanii (38 olgu), Pseudomonas aeruginosa (13 olgu) ve Klebsiella pneumoniae (7 olgu)'dir.

Askorbik asit alan olguların 12'sinde (\%36.4) akut böbrek hasarı gelisisiken, almayanların 15 'inde (\%45.5) gelișmiștir $(\mathrm{p}=0.617)$. Askorbik asit alan hastalarda akut böbrek yetmezliği $9.1 \pm 5.9$ günde gelisisiken, almayanlarda $7.1 \pm 4.4$ günde gelișmiștir $(p=0.314)$. Askorbik asit alan hastalarda nefrotoksisite gelișme oranı daha düsüu ve nefrotoksisitenin daha uzun sürede geliștiği görülmekle birlikte istatistiksel olarak anlamlı bulunmamıstır. Askorbik 
Tablo 1. Olguların askorbik asit kullanımına göre demografik özellikleri

\begin{tabular}{|c|c|c|c|}
\hline & Askorbik asit $(+)(n=33)$ & Askorbik asit (-) (n= 33) & $\mathbf{p}$ \\
\hline Yaş & $64.8 \pm 17.4$ & $65.05 \pm 21.7$ & 0.881 \\
\hline Cinsiyet (Erkek/Kadın) & $21 / 12$ & $23 / 10$ & 0.794 \\
\hline \multicolumn{4}{|l|}{ Ek hastalıklar, n (\%) } \\
\hline Kalp hastalığı & $6(18.9)$ & $6(18.9)$ & 1 \\
\hline Malignite & $13(39.4)$ & $4(12.1)$ & 0.023 \\
\hline Diyabetes mellitus & $6(18.9)$ & $4(12.1)$ & 0.733 \\
\hline Kronik obstrüktif akciğer hastalığı & $5(15.2)$ & $7(21.2)$ & 0.751 \\
\hline Obezite & $3(9.1)$ & 0 & 0.238 \\
\hline \multicolumn{4}{|l|}{ Kolistin kullanım endikasyonları, n (\%) } \\
\hline Pnömoni (HKP+ViP) & $20(60.6)$ & $27(81.8)$ & 0.90 \\
\hline Üriner sistem infeksiyonu & $4(12.1)$ & $5(15.2)$ & 1 \\
\hline Deri ve yumuşak doku infeksiyonu & $2(6.1)$ & $1(3.0)$ & 1 \\
\hline Bakteriyemi & $1(3.0)$ & $1(3.0)$ & 1 \\
\hline Kateter ilişkili kan dolaşımı infeksiyonu & $2(6.1)$ & 0 & 0.492 \\
\hline Cerrahi alan infeksiyonu & $1(3.0)$ & 0 & 1 \\
\hline TKP & $1(3.0)$ & $1(3.0)$ & 1 \\
\hline Diğer & $3(9.1)$ & 0 & 0.238 \\
\hline
\end{tabular}

Tablo 2. Askorbik asit kullanımına göre ABH gelişimi ve risk faktörleri

\begin{tabular}{lccc} 
& Askorbik asit $(+)(\mathrm{n}=33)$ & Askorbik asit $(-)(\mathrm{n}=33)$ & p \\
\hline Akut böbrek hasarı gelişimi n (\%) & $12(36.4)$ & $15(45.5)$ & 0.617 \\
ABH gelişme günü & $9.1 \pm 5.9$ & $7.1 \pm 4.4$ & 0.314 \\
Kümülatif kolistin dozu (mg) & 4183.3 & 3324.2 & 0.101 \\
Kolistin nebül kullanımı n (\%) & $18(54.5)$ & $15(45.5)$ & 0.623 \\
Nefrotoksik ajan kullanımı n (\%) & $17(53.1)$ & $12(36.4)$ & 0.216 \\
Septik şok & $10(30.3)$ & $19(57.6)$ & 0.046 \\
Albumin (g/dL) & $3.1 \pm 0.5$ & $2.9 \pm 0.5$ & 0.211
\end{tabular}

asit grubunda kümülatif kolistin dozunun daha yüksek olduğu görülmüștür (Tablo 2). Askorbik asit alan hastalarda septik sok gelișme oranı (\%30.3 vs \%57.6, $\mathrm{p}=0.046$ ) daha düșük bulunurken, klinik yanit açısından gruplar benzerdir.

Akut böbrek yetmezliği gelișen 27 hasta yaș, cinsiyet, askorbik asit kullanımı, albümin, nefrotoksik ajan kullanımı, sepsis varlığı, inotrop gerekliliği, NAC kullanımı açısından değerlendirildiğinde; ileri yas $(72.6 \pm 13.8$ vs $60.1 \pm 21.4, p=0.005)$ ve sepsis varlhğında (\%59.3 vs $\% 33.3 \mathrm{p}=0.046)$ daha sı $\mathrm{ABH}$ geliștiği görülmüștür. Diğer parametreler açısından istatistiksel olarak anlaml fark bulunmamıștır. Ek hastalıklar açısından değerlendirildiğinde, altta yatan kardiyak hastalığın akut böbrek hasarı gelișimi için (\%37.0 vs \%5.1, p= 0.01) risk faktörü olduğu saptanmıștır (Tablo 3).

\section{TARTIȘMA}

Kolistinin en sık görülen yan etkisi olan nefrotoksisite doza bağımlı olarak gelișmekle birlikte, tedavinin kesilmesinin ardından akut böbrek hasarında iyileșme görülebilmektedir ${ }^{[12]}$. Kolistin iliskili 
Tablo 3. Akut böbrek hasarı gelişimine göre olguların karşılaştırılması

\begin{tabular}{|c|c|c|c|}
\hline & $\mathrm{ABH}(+)(n=27)$ & ABH $(-)(n=39)$ & p \\
\hline Yaş & $72.6 \pm 13.8$ & $60.1 \pm 21.4$ & 0.005 \\
\hline Cinsiyet (Erkek/Kadın) & $16 / 11$ & $28 / 11$ & $>0.05$ \\
\hline $\begin{array}{l}\text { Ek hastalıklar, n (\%) } \\
\text { Kalp hastalığı } \\
\text { Malignite } \\
\text { Diyabetes mellitus } \\
\text { Kronik obstrüktif akciğer hastalığı } \\
\text { Obezite }\end{array}$ & $\begin{array}{l}10(37.0) \\
6(22.2) \\
5(18.5) \\
5(18.5) \\
1(10.0)\end{array}$ & $\begin{array}{c}2(5.1) \\
11(28.2) \\
5(12.8) \\
7(17.9) \\
2(5.1)\end{array}$ & $\begin{array}{c}0.01 \\
>0.05 \\
>0.05 \\
>0.05 \\
>0.05\end{array}$ \\
\hline Askorbik asit kullanımı n (\%) & $12(44.4)$ & $21(53.8)$ & $>0.05$ \\
\hline Albumin (g/dL) & $2.9 \pm 0.37$ & $3.09 \pm 0.55$ & $>0.05$ \\
\hline Nefrotoksik ajan kullanımı n (\%) & $12(44.4)$ & $17(43.5)$ & $>0.05$ \\
\hline Sepsis n (\%) & $16(59.3)$ & $13(33.3)$ & 0.046 \\
\hline İnotrop gerekliliği n (\%) & $15(55.5)$ & $15(38.4)$ & $>0.05$ \\
\hline NAC kullanımı n (\%) & $11(40.7)$ & $23(58.9)$ & $>0.05$ \\
\hline
\end{tabular}

ABH'nin patogenezi net olarak aydınlatılamasa da su ana kadar yapılan calışmalar akut tübüler nekrozun altta yatan nedeninin oksidatif stres ve apoptozise bağlı olduğunu desteklemektedir. Ülkemizde son yıllarda yapılan değisik calısmalarda kolistin kullanan hastalarda gelișen nefrotoksisite oranları \%35-69.7 arasında değișmektedir. Calıșmamızda da toplam 66 hastanın 27'sinde (\%40.9) kolistin ilișkili nefrotoksisite gelișmiș olup ülkemizdeki sonuçlar ile benzer özellik göstermektedir ${ }^{[13-16]}$

Askorbik asit bir monosakkarit türevi olup çoğu organizmada sentezlenebilmesine rağmen, L-askorbik asit biyosentezinin son basamağını katalize eden L-gulono-g-lakton oksidaz enzim eksikliği nedeniyle insanda sentezlenemeyen cok önemli bir vitamindir ${ }^{[17]}$. Ağızdan alındığında, plazma ve doku konsantrasyonları sağlıklı insanlarda emilim, doku birikimi, renal atılım ve yeniden emilim olmak üzere en az 4 mekanizma ile sıkı bir sekilde kontrol edilmektedir. Oral yolla alındığında doza bağımlı olarak emilim azalmaktadır ve ulassılabilecek maksimum plazma konsantrasyonu 250 $\mu \mathrm{mol} / \mathrm{L}$ kadardır. Aksine, askorbik asit intravenöz olarak uygulandığında plazma konsantrasyonu 25$30 \mathrm{mmol} / \mathrm{L}$ seviyelerine clkabilmektedir ${ }^{[18]}$. Literatürde NAC ve askorbik asidin koruyucu etkinliği ile ilgili preklinik çalıșmalar mevcuttur ${ }^{[8,9,19]}$.
Ceylan ve arkadașları tarafından NAC'in kolistine bağlı gelișen nefrotoksisiteyi önleyici etkisini araștırdıkları hayvan calıșmasında, kolistin ile es zamanlı verilen NAC'in böbrek dokusunda endotelyal nitrik oksit sentaz (eNOS), süperoksit dismutaz 2 (SOD2) ve matris metalloproteinaz 3 (MMP3) ekspresyonunu arttırarak histolojik olarak böbrek hasarını önleyebileceği belirtilmiștir ${ }^{[9]}$. Kontrast nefropatisinin önlenmesinde de NAC etkinliğini araștıran ve gösteren birçok calıșma mevcut olsa da yapılan yayınlarda celiskkili sonuclar elde edilmiș ve daha ileri calıșmalara ihtiyac olduğu belirtilmiștir ${ }^{[20]}$.

Dalfino ve arkadașlarının üçüncü basamak yoğun bakım ünitesinde sepsis veya septik sok tanısıyla kolistin tedavisi alan 70 hastayı takip ettikleri prospektif calıșmada; ileri yas, bazal renal bozukluk ve sepsis siddetinin akut böbrek hasarı ile iliskili olduğu saptanmıștır. Kolistin ile es zamanlı askorbik asit alan grupta ise istatistiksel olarak anlaml sekilde $(p=.003)$ daha az sıkllkla akut böbrek hasarı görüldüğü ayrıca hastanın yașına, bazal renal bozukluğuna ve sepsisin siddetine bakılmaksızın, askorbik asidin güclü bir böbrek koruyucu rolünün olduğu belirtilmiștir [7]. Çalıșmamızda ileri yaș, sepsis varlığı ve kardiyak hastalık varlığının kolistin kullanan hastalarda nefrotoksisite gelișimine zemin hazırladığı tedavide es zamanlı askorbik asit alan 
grupta ise akut böbrek hasarının istatistiksel olarak anlamlı olmasa da hem daha az sıklikla hem de daha uzun süre zarfında görülmesinin önemli bir bulgu olduğunu düșünüyoruz.

Kolistin nefrotoksisite riskini arttıran faktörler birçok calıșmada tanımlanmıștır. Bunlar; ileri yas, hipovolemi, kronik böbrek hastalığı, malignite, anemi, hipoalbuminemi, yanı, travma, majör cerrahi uygulaması, septik sok, nefrotoksik ajan maruziyeti, erkek cinsiyet olarak rapor edilmiștir ${ }^{[6,7]}$. Calıșmamızda ileri yaș, sepsis varlığı ve komorbidite olarak kalp hastalığının eșlik etmesinin renal yetmezlik gelișimini etkilediği saptanmıștır. Kolistin ile birlikte aminoglikozid, vankomisin, intravenöz kontrast madde, diüretik, non-steroid antiinflamatuar ajan, amfoterisin B gibi ilaçların nefrotoksisiteye etkisini değerlendiren calıșmalarda; tek değișkenli analizde kolistin ile birlikte nefrotoksik ajan kullanımının, kolistin nefrotoksisitesini artırdığı görülse de yapılan çok değișkenli analizlerde etkisinin olmadığı izlenmiștir ${ }^{[21]}$. Coskun ve arkadașlarının gram-negatif infeksiyonlarda kolistinin etkinliğinin değerlendirdikleri tez çalıșmasında, kolistin ile birlikte nefrotoksik ilac kullanımının nefrotoksisite gelișimine etkisinin olmadığ1; nefrotoksisite gelișmesini belirleyen tek faktörün hastanın yașı $(60.6 \pm 2.2$ vs $49.4 \pm 1.7, p<0.001)$ olduğu gözlenmiștir ${ }^{[22]}$.

Çalıșmamızda, kolistin ile eș zamanlı askorbik asit almıs hastalarda septik sok gelisiminin almayanlara göre istatistiksel olarak anlaml sekilde daha az sıklıkla saptanması dikkat çekicidir. Bu konuyla ilgili literatürde sınırlı sayıda veri vardır. Zabet ve arkadașlarının yoğun bakım ünitesinde, vazopressör tedavi gerektiren septik sok tanısıyla izlenen 28 içeren çalıșmalarında; yüksek doz askorbik asit (6 saatte bir $25 \mathrm{mg} / \mathrm{kg}$ ) verilen grup plasebo ile karșlaștırılmıs, askorbik asit alan grupta norepinefrin dozu ve tedavi süresinde anlamlı olarak azalma görülduiğui bildirilmiștir. Ayrıca askorbik asit tedavisi alanlarda 28 günlük mortalite de anlamlı olarak daha az saptanmıstır ${ }^{[23]}$. Lin ve arkadașlarının dört randomize kontrollü çalıșma ile iki retrospektif calıșmayı dahil ederek gerçekleștirdikleri meta-analizde sepsis ve septik sok tanısıyla izlenen hastalarda özellikle yüksek doz (>50 mg/kg/gün) askorbik asit kullanımının mortaliteyi azalttığı ifade edilmiștir ${ }^{[24]}$. Askorbik asit uzun yıllar kanser hastalarında denenmis olup prognoz üzerine olumlu etkileri olduğu gösterilmiștir. Ancak optimal dozla ilgili araștırma cok az sayıdadır $^{[25-27]}$. Grooth ve arkadașları tarafından, optimal dozu saptamak amaciyla, kritik hastalar üzerinde yapılmıs randomize kontrollü çalıșmada; askorbik asit bir gruba 2 gr/gün, diğer gruba 10 gr/gün intravenöz uygulamıștır. 2 gr/gün verilen grupta herhangi bir etki görülmezken, 10 gr/gün alan grupta plazma düzeyleri cok yüksek ölçülmüs olup metabolik alkaloz ve oksalat atılımı saptanmıștır ${ }^{[28]}$. Calıșmamızda yalnızca 3 gr/gün askorbik asit alan hastalar dahil edilmiș olup herhangi bir yan etki gerçeklesmemiștir.

Sunulan çalıșmanın retrospektif olması ve dahil edilen hasta sayısının sinırlı olması ile hasta grubunun tedavi yapilan infeksiyonlar açısından homojen olmaması en önemli kısıtlılıklarıdır. Hasta sayısı az olmakla birlikte askorbik asidin kolistin nefrotoksisitesi üzerine etkisini değerlendiren sınırl sayıda calıșma olduğu unutulmamalıdır.

Sonuç olarak çalıșmamızda istatistiksel anlamlllık düzeyine ulașmasa da elde ettiğimiz verilere göre kolistine bağlı nefrotoksisitenin, askorbik asit kullanımıyla sıklığının azalabileceğini ve/veya daha geç dönemde ortaya çkabileceğini düșuinmekteyiz. Ayrıca calıșmamızda askorbik asit kullanımı ile sepsis gelișiminin istatistiksel olarak anlaml sekilde daha az saptanması, ciddi bir yan etkisinin olmaması ve özellikle literatürde sepsis ve septik sok gibi kritik hasta gruplarında mortaliteyi azalttığına dair calıșmalarında bulunması göz önüne alındığında, askorbik asit kullanımının faydalı olabileceğini düșünmekteyiz ${ }^{[29]}$. Hiç șüphesiz ki bu uygulamanın günlük pratiğimize girebilmesi için geniș olgu serili, prospektif, randomize kontrollü çalıșmalara ihtiyaç vardir.

\section{ETIKK KURUL ONAYI}

$\mathrm{Bu}$ çalıșma için Ege Úniversitesi Tıp Fakültesi Tıbbi Araștırmalar Etik Kurulundan onay alınmıștır (Tarih: 29.05.2020 Karar no: 20-5.IT/51).

\section{ÇIKAR ÇATIŞMASI}

Yazarlar bu makale ile ilgili herhangi bir c1kar çatıșması bildirmemișlerdir. 


\section{YAZAR KATKISI}

Anafikir/Planlama: MIT, PKE, FB

Analiz/Yorum: MIT, MST, HP

Veri sağlama: PKE, ÇY, DA

Yazım: HAE, CYY, DA

Gözden Geçirme ve Düzeltme: MIT, FB, HP, MST

Onaylama: MIT, FB

\section{KAYNAKLAR}

1. Falagas ME, Kasiakou SK, Saravolatz LD. Colistin: the revival of polymyxins for the management of multidrug-resistant gram-negative bacterial infections. Clinical infectious diseases 2005;40(9):1333-41

2. Conly JM, Johnston BL. Colistin: the phoenix arises. Canadian Journal of Infectious Diseases and Medical Microbiology 2006;17.

3. Wallaces J, Li J, Rayner CR, Coulthard K, Nation RL. Stability of Colistin Methanesulfonate in Pharmaceutical Products and Solutions for Administration to Patients. Antimicrobial Agents and Chemotherapy 2008;52(9),3047-51.

4. Yapa SWS, Li J, Porter CHJ, Nation RL, Patel K, Mcintosh MP. Population pharmacokinetics of colistin methanesulfonate in rats: Achieving sustained lung concentrations of colistin for targeting tespiratory infections. Antimicrobial Agents and Chemotherapy 2013;57(10),5087-5095.

5. Gantenbein, Urs Leo. "Poison and its dose: Paracelsus on toxicology." Toxicology in the middle ages and renaissance. Academic Press 2017:1-10.

6. Spapen H, Jacobs $R$, Gorp V, Troubleyn J, Honoré P. Renal and neurological side effects of colistin in critically ill patients. Annals of Intensive Care 2011,1:14

7. Dalfino L, Puntillo F, Ondok M, Mosca A, Monno R, Coppolecchia S, Spada M, Bruno F, Brienza N. Colistin-associated acute kidney injury in severely ill patients: A step toward a better renal care? A prospective cohort study. Clin Infect Dis 2015;61(12):1771-7.

8. Ozyilmaz E, Ebinc FA, Derici U, Gulbahar O, Goktas G, Elmas $C$, Oguzulgen IK, Sindel S. Could nephrotoxicity due to colistin be ameliorated with the use of $N$-acetylcysteine? Intensive Care Med 2011;37(1):141-6

9. Ceylan B, Ozansoy $M$, Kılıç Ü, Yozgat $Y$, Ercan Ç, Yıldız $P$, Aslan T. N-acetylcysteine suppresses colistimethate sodium-induced nephrotoxicity via activation of SOD2, eNOS, and MMP3 protein expressions. Ren Fail 2018;40(1):423 34

10. Clinical Practice Guideline for Acute Kidney Injury. Official Journal of the International Society of Nephrology 2012;2(1)

11. Surviving Sepsis Campaign: International Guidelines for Management of Severe Sepsis and Septic Shock: 2012. Crit Care Med 2013;41(2):580-637
12. Bergen PJ., Landersdorfer CB., Zhang J, Zhao M, Lee HJ, Nation RL, Li J. Pharmacokinetics and pharmacodynamics of 'old'polymyxins: what is new? Diagnostic microbiology and infectious disease 2012;74(3):213-23.

13. Coşkun B, Azap A, Yılmaz G, Ayhan M, Sarıcaoğlu EM. Assessment of colistin treatment in multidrug-resistant Gram-negative bacterial infections. Klimik Dergisi 2020;33(2):142-7.

14. Kaya M, Tunçel Yi, Kuru RN, Menteş S, Ünver S, Çeken $S$, Ertek M. Retrospective evaluation of colistin associated nephrotoxicity at oncology hospital intensive care unit. Türk Yoğun Bakım Derneği Dergisi 2014;12:51-6.

15. Efe Kaplan F, Ebinç FA, Karakaya S, Karadağ I, Eser M, Ünsal O, Kutlugün Aybal A, Beyan E. Evaluation of colistin nephrotoxicity in intensive care diseases of patients. Abant Med J 2018;7(1):10-14.

16. Arslan Zi, Özbudak E, Türkyılmaz N, Cesur S, Alparslan V, Mirhanoğulları AF, Baykara ZN, Toker K, Solak M. Evaluation of the use of colistin on nephrotoxicity and mortality in the intensive care unit. Turkiye Klinikleri J Anest Reanim 2015;13(1):21-4.

17. Nishikimi M, Fukuyama R, Minoshima S, Shimizu N, Yagi K. Cloning and chromosomal mapping of the human nonfunctional gene for L-gulono-gamma-lactone oxidase, the enzyme for L-ascorbic acid biosynthesis missing in man. Journal of Biological Chemistry 1994; 269:13685-8.

18. Levine M, Padayatty SJ, Espey MG. Vitamin C: a concentration function approach yields pharmacology and therapeutic discoveries. Advances in nutrition 2011;2:78-88

19. Yousef JM, Chen G, Hill PA, Nation RL, Li J. Ascorbic acid protects against the nephrotoxicity and apoptosis caused by colistin and affects its pharmacokinetics. J. Antimicrob. Chemother 2012;67:452-9.

20. Türkoğlu M. Yoğun bakımda akut böbrek hasarının önlenmesi. Yoğun Bakım Dergisi 2008;8(2).

21. Pike $M$, Saltiel E. Colistin- and polymyxin-induced nephrotoxicity: Focus on literature utilizing the RIFLE classification scheme of acute kidney injury. Journal of Pharmacy Practice 2014;27(6):554-6

22. Coşkun B. Dirençli Gram negatif bakteri infeksiyonlarında kolistin uygulamasının sonuçlarının değerlendirilmesi. Ankara Üniversitesi Tıp Fakültesi, Uzmanlık Tezi; 2015.

23. Zabet $M H$, Mohammadi $M$, Ramezani $M$, Khalili $H$. Effect of high-dose ascorbic acid on vasopressor's requirement in septic shock. J Res Pharm Pract 2016;5(2):94-100.

24. Lin J, Li H. Wen $Y$, Zhang, M. Adjuvant administration of vitamin $C$ improves mortality of patients with sepsis and septic shock: A systems review and meta-analysis. Open Journal of Internal Medicine 2018;8:146-159.

25. Ohwada R, Ozeki $Y$, Saitoh $Y$. High-dose ascorbic acid induces carcinostatic effects through hydrogen peroxide and superoxide anion radical generation-induced cell death and growth arrest in human tongue carcinoma cells. Free Radic Res 2017;51(7-8):684-92. 
26. Maramag C, Menon M, Balaji KC, Reddy PG, Laxmanan S. Effect of Vitamin $C$ on prostate cancer cells in vitro: Effect on cell number, viability and DNA synthesis. Prostate 1997;32(3):188-95.

27. Noguera NI, Pelosi E, Angelini DF, Piredda ML et al. High-dose ascorbate and arsenic trioxide selectively kill acute myeloid leukemia and acute promyelocytic leukemia blasts in vitro. Oncotarget 2017;8(20):32550-65.

28. Grooth HJ, Manubulu-Choo WP, Zandvliet AS, Spoelstra-de Man AME, Girbes AR, Swart EL, Oudemans-van Straaten HM. Vitamin C pharmacokinetics in critically ill patients: A randomized trial of four IV regimens. Chest 2018;153(6):1368-77.
29. Wang $Y$, Lin H, Lin BW, Lin JD. Effects of different ascorbic acid doses on the mortality of critically ill patients: a meta-analysis. Annals of intensive care 2019; 9(1):58.

\section{Yazıșma Adresi/Address for Correspondence}

Asistan Dr. Deniz AKYOL

Ege Üniversitesi Tip Fakültesi,

İnfeksiyon Hastalıkları ve

Klinik Mikrobiyoloji Anabilim Dalı,

İzmir-Türkiye

E-posta: yavuzleyla@hotmail.com 